\title{
Motivasi Berprestasi Mahasiswa di Masa Pandemi Covid-19
} (Penelitian pada Mahasiswa Fakultas Ilmu Pendidikan Universitas Negeri Gorontalo)

\author{
Maryam Rahim \\ Universitas Negeri Gorontalo \\ maryamrahim63@gmail.com \\ Wenny Hulukati \\ Universitas Negeri Gorontalo \\ wennyhulukati@ung.ac.id \\ Tuti Wantu \\ Universitas Negeri Gorontalo \\ tutiwantu@ung.ac.id
}

Received: 09 Juny 2021; Revised: 26 July 2021; Accepted: 28 August 2021

DOI: http://dx.doi.org/10.37905/aksara.7.3.1295-1302.2021

\begin{abstract}
Abstrak
Motivasi berprestasi merupakan salah satu faktor penting dalam keberhasilan studi. Rendahnya motivasi berprestasi seringkali menyebabkan banyak mahasiswa yang gagal dalam studi. Permasalahan penelitian ini adalah bagaimana motivasi berprestasi mahasiswa Fakultas Ilmu Pendidikan di masa pandemic covid-19?. Penelitian ini bertujuan untuk memperoleh gambaran tentang motivasi berprestasi mahasiswa Fakultas Ilmu Pendidikan Universitas Negeri Gorontalo di masa pandemic covid-19. Penelitian ini menggunakan metode penelitian deskriptif yang mengkaji variabel motivasi berprestasi pada mahasiswa Fakultas Ilmu Pendidikan Universitas Negeri Gorontalo. Anggota populasi adalah seluruh mahasiswa Fakultas Ilmu Pendidikan Universitas Negeri Gorontalo tahun akademik 2020/2021 yang berjumlah 2111 orang, dengan anggota sampel sebesar 10\% dari anggota populasi. Data dikumpulkan melalui angket. Analisis data menggunakan analisis deskriptif kuantitatif. Hasil penelitian menunjukkan: (a) motivasi berprestasi mahasiswa jurusan Bimbingan dan Konseling memperoleh skor ratarata $183(3,66)$ dengan kategori tinggi (b) motivasi berprestasi mahasiswa jurusan Manajemen Pendidikan memperoleh skor rata-rata 180 (3,60) dengan kategori tinggi, (c) motivasi berprestasi mahasiswa jurusan Pendidikan Luar Sekolah memperoleh skor ratarata 180 (3,60) dengan kategori tinggi, (d) motivasi berprestasi mahasiswa jurusan Pendidikan Guru Sekolah Dasar memperoleh skor rata-rata $172(3,45)$ dengan kategori tinggi, dan (e) motivasi berprestasi mahasiswa jurusan Pendidikan Guru Pendidikan Anak Usia Dini memperoleh skor rata-rata $172(3,45)$ dengan kategori tinggi. Secara keseluruhan skor rata-rata motivasi berprestasi mahasiswa Fakultas Ilmu Pendidikan Universitas Negeri Gorontalo di masa pandemi covid-19 adalah 178 (3,58) dengan kategori tinggi.
\end{abstract}

Kata Kunci: motivasi berprestasi, pandemi covid-19

\section{PENDAHULUAN}

Keberhasilan dalam studi selalu menjadi dambaan setiap mahasiswa. Berbagai upaya telah dipertimbangkan dan dilakukan agar mencapai keberhasilan studi yang telah 
ditargetkan itu. Academic achievement is an important issue. Many studies indicate that student achievement and academic success in any selected course of study is complex in nature and related to multiple variables (Carrick, 2010 dalam Bakhtiarvanda, Firoozeh., Ahmadiana, Sana., Delrooza, Kazem., Farahanib, Hojjat A. 2011). Salah satu faktor penting dalam keberhasilan studi mahasiswa, bahkan dalam kehidupan seseorang adalah motivasi berprestasi. Banyak mahasiswa yang memperoleh hasil belajar yang tidak sesuai kemampuannya, terlambat menyelesaikan studi, bahkan gagal dalam menyelesaikan studi disebabkan rendahnya motivasi berprestasi dari mahasiswa tersebut. Oleh sebab itu setiap mahasiswa hendaknya memiliki motivasi berprestasi yang tinggi.

Terdapat berbagai gejala yang merupakan indikasi rendahnya motivasi berprestasi di kalangan mahasiswa. Gejala dimaksud antara lain: sering menunda-nunda penyelesaian tugas, menyontek pekerjaan teman, melakukan plagiat, hasil belajar tidak sesuai dengan kemampuan, disiplin waktu dan disiplin belajar yang rendah, tidak aktif dalam proses perkuliahan, sering bolos kuliah, membutuhkan waktu yang panjang dalam meyelesaikan studi, bahkan mengalami putus kuliah atau drop-out. Gejala seperti ini terjadi juga di kalangan mahasiswa Fakultas Ilmu Pendidikan Universitas Negeri Gorontalo. Rendahnya motivasi berprestasi tersebut jika tidak memperoleh perhatian dari pihak yang berkepentingan dalam hal ini dosen dan pimpinan jurusan dikhawatirkan akan memberikan dampak negatif pada proses dan hasil belajar mahasiswa, yang akan berimbas pada kualitas lulusan. Perhatian ini menjadi sangat penting di masa pandemi covid-19 yang terjadi saat ini, di mana aktivitas belajar dibatasi dan diselenggarakan secara daring. Pandemi covid-19 telah mempengaruhi berbagai aspek kehidupan manusia di seluruh dunia, termasuk aspek pendidikan. Permasalahan penelitian ini adalah: Bagaimana profil motivasi berprestasi mahasiswa Fakultas Ilmu Pendidikan Universitas Negeri Gorontalo di masa pandemi covid-19? Penelitian ini bertujuan untuk mengetahui profil motivasi berprestasi mahasiswa di masa pandemi Fakultas Ilmu Pendidikan Universitas Negeri Gorontalo.

\section{METODE}

Penelitian ini merupakan penelitian deskriptif kuantitatif. Variabel penelitian adalah motivasi berprestasi, dengan indikator: (a) mempunyai keinginan untuk bersaing secara sehat dengan dirinya sendiri maupun dengan orang lain, (b) mempunyai keinginan bekerja dengan baik, (c) berpikir realistis, mengetahui kemampuan serta kelemahan dirinya, (d) memiliki tanggung jawab pribadi, (e) mampu membuat terobosan dalam berpikir, (f) berpikir strategis dalam jangka panjang, dan (g) selalu memanfaatkan umpan balik untuk perbaikan.

Anggota populasi adalah seluruh mahasiswa Fakultas Ilmu Pendidikan Universitas Negeri Gorontalo tahun akademik 2020/2021 yang berjumlah 2111 orang, tersebar dalam 5 (lima) jurusan, yakni: Bimbingan dan Konseling (312 orang), Manajemen Pendidikan (392 orang), Pendidikan Luar Sekolah (136 orang), Pendidikan Guru Sekolah Dasar (828 orang), dan Pendidikan Guru Pendidikan Anak Usia Dini (439 orang). Anggota sampel sebesar $10 \%$ dari anggota populasi, yang ditetapkan dengan menggunakan proporsional random sampling. Pengumpulan data menggunakan teknik angket. Analisis data menggunakan analisis statistik deskriptif yang divisualisasikan dalam grafik. Kategori motivasi berprestasi yang digunakan adalah: skor 200 - 250 (sangat tinggi), skor 149-199 (tinggi), skor 98-148 (sedang), 50 - 97 (rendah), dan 0-49 (sangat rendah). 


\section{HASIL DAN PEMBAHASAN HASIL}

Hasil penelitian menunjukkan: (a) motivasi berprestasi mahasiswa jurusan Bimbingan dan Konseling memperoleh skor rata-rata $183(3,66)$ dengan kategori tinggi (b) motivasi berprestasi mahasiswa jurusan Manajemen Pendidikan memperoleh skor rata-rata $180(3,60)$ dengan kategori tinggi, (c) motivasi berprestasi mahasiswa jurusan Pendidikan Luar Sekolah memperoleh skor rata-rata $180(3,60)$ dengan kategori tinggi, (d) motivasi berprestasi mahasiswa jurusan Pendidikan Guru Sekolah Dasar memperoleh skor rata-rata $172(3,45)$ dengan kategori tinggi, dan (e) motivasi berprestasi mahasiswa jurusan PGPAUD memperoleh skor rata-rata $172(3,45)$ dengan kategori tinggi. Secara keseluruhan skor rata-rata motivasi berprestasi mahasiswa Fakultas Ilmu Pendidikan Universitas Negeri Gorontalo di masa pandemi covid-19 adalah $178(3,58)$ dengan kategori tinggi.

Lebih jelasnya, hasil ini ditunjukkan dalam grafik 1 dan 2 berikut:

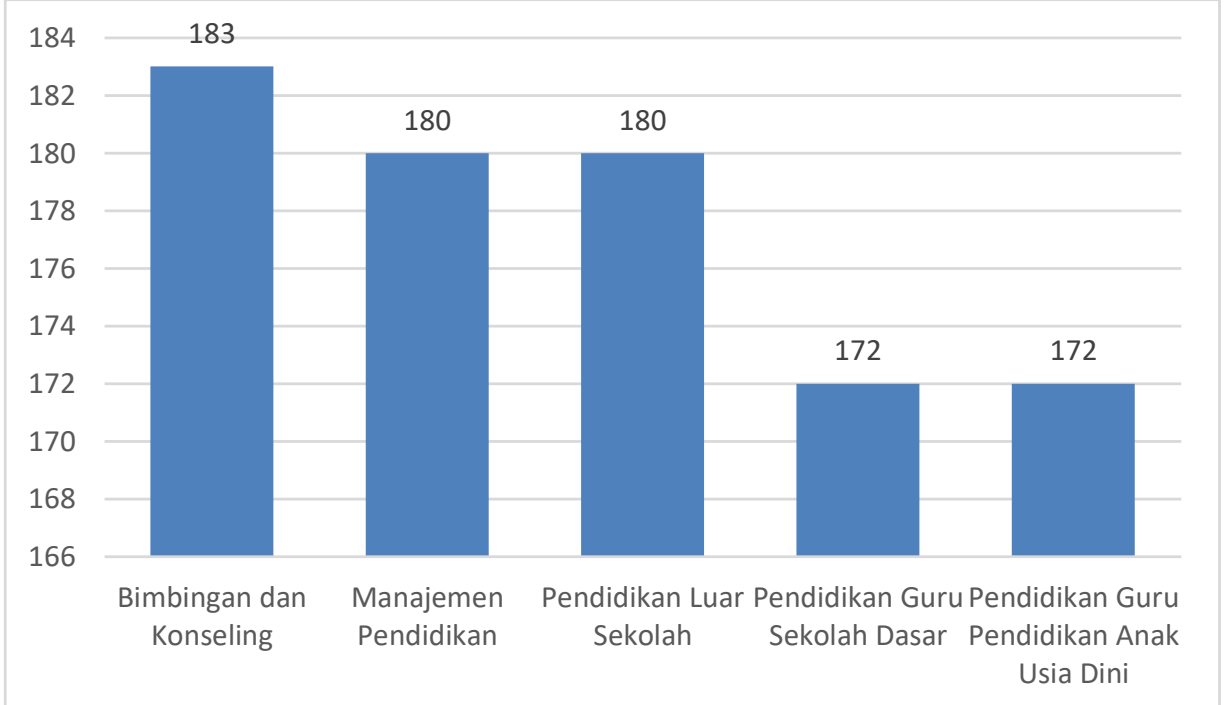

Grafik 1: Motivasi Berprestasi Mahasiswa Berdasarkan Jumlah Skor

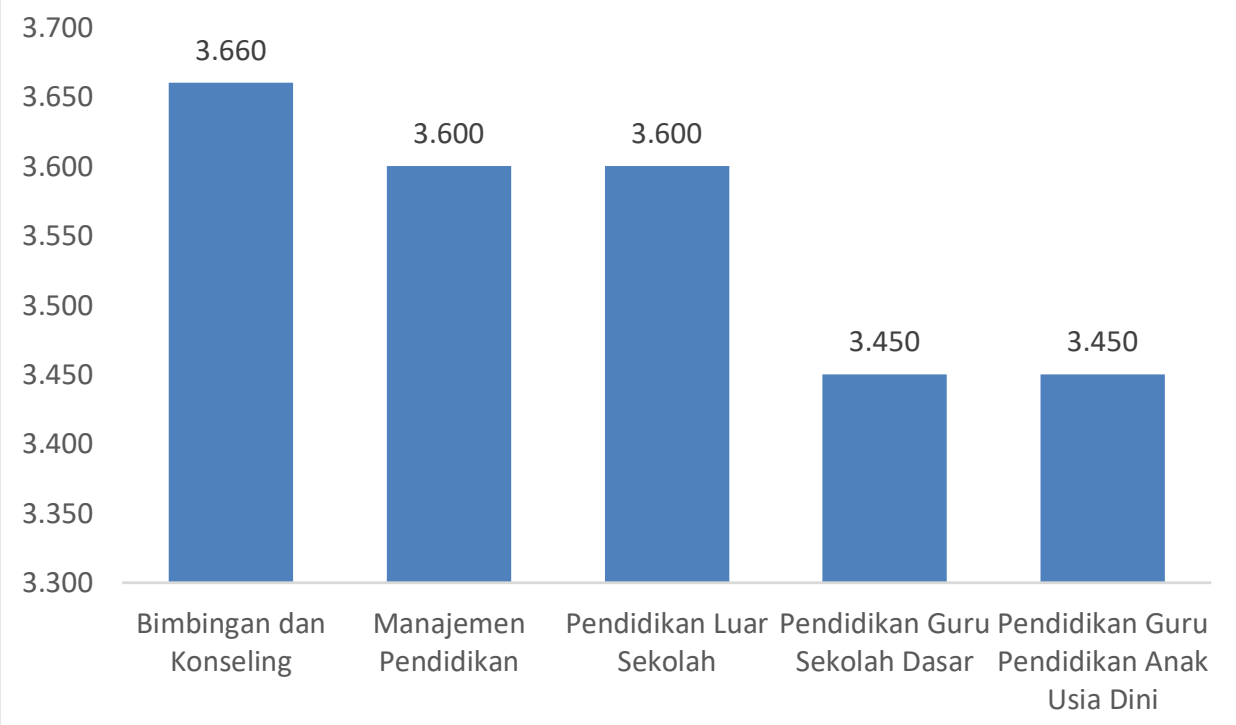

Grafik 2: Motivasi Berprestasi Berdasarkan Skor Rata-Rata 


\section{PEMBAHASAN}

Motivasi berprestasi dapat diartikan sebagai kekuatan mental yang mendorong seseorang melakukan aktivitas untuk mencapai hasil yang semaksimal mungkin. McClelland (1987:40) memberikan pengertian motivasi berprestasi sebagai usaha mencapai sukses atau berhasil dalam kompetisi dengan suatu ukuran keunggulan yang dapat berupa prestasi orang lain maupun prestasi sendiri. McClelland menggunakan istilah Need for Achievement ( $N$-Ach) untuk menyebut motivasi berprestasi. Menurut Heckhausen (dalam Haditono 1979:8) standar keunggulan adalah: (a) standar keunggulan tugas (pencapaian tugas sebaik-baiknya, (b) standar keunggulan diri (pencapaian yang lebih tinggi dibandingkan dengan prestasi yang pernah dicapai sebelumnya, (c) standar keunggulan orang lain (pencapaian prestasi yag lebih tinggi dibandingkan dengan prestasi yang dicapai orang lain.

Selain itu Chaplin (2005:6) menjelaskan motivasi berprestasi adalah: (a) kecenderungan memperjuangkan kesuksesan atau memperoleh hasil yang sangat didambakan, (b) keterlibatan ego dalam suatu tugas, (c) pengharapan untuk sukses dalam melaksanakan suatu tugas yang diungkapkan oleh reaksi-reaksi. Sementara itu Lindgren (dalam Sugiyanto, 2009) mengemukakan bahwa motivasi berprestasi merupakan dorongan yang berhubungan dengan prestasi, yaitu adanya keinginan seseorang untuk menguasai rintangan-rintangan dan mempertahankan kualitas kerja yang tinggi bersaing melalui usaha-usaha yang keras untuk melebihi perbuatan yang lampau dan mengungguli orang lain. Heckhausen menjelaskan bahwa motivasi berprestasi dorongan yang terdapat dalam diri individu yang selalu berusaha atau berjuang untuk meningkatkan atau mempertahankan kemampuannya setinggi-tingginya dalam segala kegiatan dengan menggunakan standar-standar keunggulan, sehingga mencerminkan kebutuhan berprestasi yang tinggi" (Hasbullah \& Moeins, 2016). Motivasi berprestasi adalah daya juang yang konsisten dari seorang individu untuk mencapai keberhasilan dengan standar keunggulan tertentu dalam situasi persaingan (Sarangi (2015).

Mencermati pengertian motivasi berprestasi maka jelaslah bahwa setiap mahasiswa perlu memiliki motivasi berprestasi. Kepemilikan motivasi berprestasi pada diri mahasiswa memiliki fungsi: (a) menjadi kekuatan yang mendorong dan menggerakkan mahasiswa untuk melakukan berbagai aktivitasnya dengan target yang jelas serta tingkat keberhasilan yang setinggi-tingginya, (b) menjadi pemberi arah bagi mahasiswa dalam melakukan aktivitasnya, (c) menjadi kekuatan yang membuat mahasiswa memiliki semangat yang tinggi dalam melakukan aktivitasnya, ulet, tidak mudah putus asa, dan selalu menemukan solusi dari berbagai masalah yang dihadapinya.

Motivasi berprestasi pada diri seseorang dapat diamati melalui perilaku yang ditampilkan oleh orang tersebut. Setiap pendidik (guru) seharusnya memiliki pemahaman tentang ciri-ciri perilaku siswa/mahasiswa yang memiliki motivasi beprestasi yang tinggi. Pemahaman ini akan sangat membantu pendidik (guru) dalam menumbuhkan dan meningkatkan motivasi berprestasi di kalangan siswa/mahasiswa. Setiap pendidik (guru) juga harus senantiasa memahami bahwa tugasnya tidak terbatas pada mengajar, namun juga bertanggung jawab dalam mengembangkan berbagai kemampuan ataupun potensi yang dimiliki oleh siswa/mahasiswa yang menjadi faktor pendukung dalam pencapaian prestasi yang maksimal.

Menurut Mussen, et al (1994:307) motivasi berprestasi seringkali ditunjukkan dalam bentuk perilaku, seperti tekun dalam tugas yang sulit, bekerja giat untuk mencapai 
penguasaan, dan memilih tugas yang menantang tetapi tidak terlalu sulit. McClelland (1987) menjelaskan bahwa individu yang memiliki motivasi berprestasi tinggi akan mempunyai rasa tanggung jawab dan rasa percaya diri yang tinggi, lebih ulet, lebih giat dalam melaksanakan suatu tugas, mempunyai harapan yang tinggi untuk sukses, dan mempunyai keinginan untuk menyelesaikan tugasnya dengan baik. Selain itu menurut McClelland (1987) ciri-ciri individu yang memiliki motivasi berprestasi yang tinggi adalah: (a) mempunyai keinginan untuk bersaing secara sehat dengan dirinya sendiri maupun dengan orang lain, (b) mempunyai keinginan bekerja dengan baik, (c) berpikir realistis, tahu kemampuan serta kelemahan dirinya, (d) memiliki tanggung jawab pribadi, (e) mampu membuat terobosan dalam berpikir, (f) berpikir strategis dalam jangka panjang, dan (g) selalu memanfaatkan umpan balik untuk perbaikan.

Menurut French (dalam Sugiyanto, 2003) siswa yang memiliki motivasi beprestasi yang tinggi akan bertahan lebih lama pada tugas dibandingkan dengan siswasiswa yang memiliki motivasi berprestasi rendah, meskipun mereka mengalami kegagalan. Mereka akan menghubungkan kegagalan mereka dengan kurangnnya usaha, dan bukan dengan faktor-faktor eksternal seperti kesukaran tugas, ataupun keberuntungan. Siswa yang memiliki motivasi berprestasi yang tinggi selalu menginginkan keberhasilan, dan ketika mereka gagal akan melipatgandakan usaha mereka sehingga dapat berhasil.

Pandemi covid-19 yang terjadi sejak tahun 2019 telah mempengaruhi kehidupan psikologis siswa/mahasiswa. Pengaruh tersebut dapat saja bersifat positif dan juga negatif. Pengaruh positif antara lain: melatih kemandirian siswa dalam belajar, mengembangkan kemampuan menggunakan teknologi informasi baik pada diri siswa, guru, maupun orang tua, meningkatkan keterlibatan orang tua dalam pendidikan anaknya. Pengaruh negatif antara lain: membatasi interaksi sosial antara sesama siswa, interaksi siswa dengan guru, dan masyarakat pada umumnya, menimbulkan rendahnya aktivitas belajar pada sebagian siswa, kecemasan, ketakutan pada masyarakat.

Antara kedua pengaruh tersebut, yang dikhawatirkan adalah pengaruh negatif dari covid-19. Pengaruh negatif tersebut telah menimbulkan kekhawatiran berbagai pihak, sebagaimana dikemukakan oleh Mozammel, Soleman; Ahmed, Umair; Shakar, Nawal (2021) bahwa selama pandemi covid-19, muncul kekhawatiran tentang masalah prestasi akademik siswa karena pergeseran kelas fisik ke online. Hammerstein; König; Dreisörner; \& Frey (2021) menemukan efek yang sangat negatif dari penutupan sekolah pada prestasi siswa khususnya pada siswa yang lebih muda dan siswa dari keluarga dengan status sosial ekonomi rendah. Namun dari aspek kecemasan belajar, hasil penelitian Anggraeni; Alpian; Kodariah; (2021) menemukan bahwa tingkat kecemasan belajar siswa sekolah dasar pada masa pandemi covid-19 tidak menunjukan tingkat kecemasan yang tinggi atau masih dibatas wajar dan masih dinilai ringan, tidak menimbulkan kecemasan yang berlebih. Selain itu peran serta orangtua dalam mendampingi dan membimbing siswa belajar di rumah terbilang efektif dapat mengatasi kecemasan belajar siswa.

Pengaruh pandemi covid-19 terhadap motivasi berprestasi. khususnya di kalangan mahasiswa tentu saja dapat berupa pengaruh negatif, dalam arti pandemi covid19 akan mengurangi motivasi berprestasi mereka; dan bisa juga berupa pengaruh positif, dalam arti pandemi covid-19 tidak akan mengurangi motivasi berprestasi mahasiswa, bahkan bisa saja justru akan meningkatkan motivasi berprestasi mereka. 
Hasil penelitian menyimpulkan bahwa motivasi berprestasi mahasiswa Fakultas Ilmu Pendidikan Universitas negeri Gorontalo di masa pandemi covid-19 berada pada kategori tinggi. Hal ini berarti bahwa mahasiswa tetap memiliki motivasi berprestasi yang tinggi meskipun pada saat sedang dalam masa pandemi covid-19 yang terjadi di seluruh dunia. Pandemi covid-19 telah berdampak pada kegiatan masyarakat, termasuk kegiatan akademik mahasiswa, di mana aktivitas masyarakat sangat terbatas, demikian juga aktivitas perkuliahan yang mengalami perubahan dari model tatap muka menjadi tatap maya atau perkuliahan dalam jaringan (daring). Namun demikian, di masa pandemi covid-19 mahasiswa Fakultas Ilmu Pendidikan Universitas Negeri Gorontalo tetap memiliki motivasi berprestasi tinggi.

Jika dikaitkan dengan hakekat motivasi berprestasi, pada dasarnya motivasi berprestasi sangat bersifat internal, dalam arti sangat berkaitan dengan kondisi internal individu. Oleh sebab itu motivasi berprestasi seseorang tidak mudah dipengaruhi oleh faktor yang berasal dari luar dirinya (faktor eksternal). Sebagaimana dikemukakan oleh Mussen et, al (1994:289), faktor-faktor yang menentukan tingkat motivasi berprestasi seseorang dalam bidang tugas tertentu yaitu: (a) nilai yang dilekatkan pada keberhasilan dalam bidang itu (nilai pencapaian atau nilai insentif), dalam hal ini penilaian tentang penting tidaknya prestasi itu pada masa depan diri sendiri; (b) harapan individu akan keberhasilan, tinggi rendahnya harapan individu atas keberhasilan yang ingin dicapai akan mempengaruhi motivasi berprestasi, dan (c) atribusi mengenai faktor penyebab seseorang berhasil atau gagal; individu yang merasa bahwa keberhasilan dan kegagalan terkendali secara internal lebih memungkinkan mengerahkan usaha untuk berprestasi dibandingkan dengan individu yang menganggap bahwa kekuatan eksternal yang mengendalikan apa yang terjadi.

Setiap mahasiswa selayaknya memiliki motivasi berprestasi yang tinggi dalam kondisi apapun, baik pada saat terjadi pandemi penyakit tertentu maupun tidak, mahasiswa harus mampu beradaptasi dengan perubahan atau situasi yang terjadi dalam kehidupan. Oleh sebab itu perlu senantiasa dilakukan berbagai upaya untuk meningkatkan dan menguatkan motivasi berprestasi mahasiswa dalam berbagai kondisi kehidupan yang dihadapinya. Upaya ini dipandang penting mengingat besarnya kontribusi motivasi berprestasi dalam pencapaian hasil belajar ataupun dalam kehidupan yang sesungguhnya. Menurut Wedhayanti, Suarni, dan Dantes (2020) upaya peningkatan mutu pendidikan dalam rangka peningkatan kualitas potensi siswa antara lain dapat dilakukan dengan meningkatkan motivasi berprestasi. Siswa dengan harapan keberhasilan akademik yang tinggi akan memiliki kecenderungan yang jelas untuk menunjukkan perilaku positif (Murayama, Pekrun, Lichtenfeld \& Vom Hofe, 2013; Prast et al., 2018, dalam Damronpanit, 2019). Motivasi berprestasi mahasiswa diharapkan semakin tinggi dan kuat dalam menyelesaikan mata kuliah dengan prestasi yang tinggi (Yuni-Astuti, 2019). Much of the recent research indicated that academic motivation is an important component in learning and achievement (Bakhtiarvanda; Ahmadiana; Delrooza; dan Farahanib; 2011).

Beberapa penelitian telah dilakukan untuk memperoleh gambaran dan mengkaji motivasi berprestasi siswa/mahasiswa. Hasil penelitian Emmanuel; Josephine; dan Solomon (2014), Sarangi (2015), Awam; Noureen; dan Naz, (2011) menunjukkan ada hubungan positif antara motivasi berprestasi dan prestasi akademik. Sebagaimana hasil penelitian Mahato dan Pranab (2019) yang menyimpulkan ada hubungan yang signifikan 
antara motivasi berprestasi akademik dengan prestasi akademik mahasiswa komunitas SC, ST di Kecamatan Purulia. Penelitian lain dilakukan oleh Sugiyanto (2009) yang menyimpulkan bahwa motivasi berprestasi berkontribusi positif dan signifikan terhadap prestasi akademik, yakni 73,96\% berkontribusi terhadap aspek kognitif; 57,75\% berkontribusi terhadap aspek afektif; dan 70,56\% berkontribusi terhadap aspek psikomotor. Hasil penelitian Bakhtiarvanda; Ahmadiana; Delrooza; dan Farahanib (2011)

Motivasi berprestasi tidak hanya berkonstribusi terhadap prestasi akademik, namun juga pada perilaku seseorang seacara umum. Hasil penelitian Adegboyega (2018) menyimpulkan adanya hubungan yang signifikan antara motivasi berprestasi dengan sikap mahasiswa Nigeria terhadap ujian. Demikian pula hasil penelitian yang dilakukan oleh Ellya (2013) menyimpulkan bahwa motivasi berprestasi memiliki pengaruh signifikan terhadap kesiapan berwirausaha pada siswa.

Hasil-hasil penelitian ini telah mendukung pentingnya siswa/mahasiswa memiliki motivasi berprestasi, mengingat motivasi berprestasi berkontribusi terhadap prestasi akademik, bahkan perilaku mahasiswa secara keseluruhan. Emmanuel; Josephine; dan Solomon (2014) menegaskan pentingnya motivasi berprestasi terhadap prestasi akademik. Oleh sebab itu setiap siswa/mahasiswa perlu memiliki motivasi berprestasi.

\section{KESIMPULAN}

Penelitian ini telah menemukan bahwa motivasi berprestasi mahasiswa Fakultas Ilmu Pendidikan Universitas Negeri Gorontalo pada masa pandemi covid-19 berada pada "kategori tinggi", yakni dengan tota skor 179 dan rata-rata 3,58. Namun demikian dipandang perlu dilakukan berbagai upaya agar motivasi berprestasi mahasiswa tersebut lebih ditingkatkan atau minimal dipertahankan.

\section{UCAPAN TERIMA KASIH}

Ucapan terima kasih disampaikan kepada pimpinan Fakultas Ilmu Pendidikan Universitas Negeri Gorontalo ang telah memfasilitasi pelaksanaan penelitian, mahasiswa Fakultas Ilmu Pendidikan Universitas Negeri Gorontaloyang yang telah menjadi subye kpenelitian, serta teman-teman kolega yang telah membantu dalam melancarkan proses pengumpulan data penelitian ini.

\section{REFERENSI}

Adegboyega. Lateef. (2018). Influences of achievement motivation on nigerian undergraduates' attitude toward examination. International Journal of Instruction 11 (1):77-88.

Anggraeni, Sri Wulan., Alpian, Yayan., Kodariah, Siti.( 2021). Primary school students' learning anxiety during the covid-19 pPandemic. International Journal of Elementary Education. Volume 5, Number 1, Tahun 2021, pp. 1-10

Awan, R., Noureen, G., \& Naz, A. (2011). A Study of relationship between achievement mMotivation, self-concept and achievement in english and mathematics at secondary level. International Education Studies, 4 (3), 72- 79.

Budiningsih, C. Asri. (2005). Belajar dan Pembelajaran. Jakarta. PT Rineka Cipta.

Bakhtiarvanda, Firoozeh., Ahmadiana, Sana., Delrooza, Kazem., Farahanib, Hojjat A. (2011). The moderating effect of achievement motivation on relationship of 
learning approaches and academic achievement. Procedia: Social and Behavioral Sciences 28 (2011) 486-488.

Chaplin, J.P. (2005). Kamus Lengkap Psikologi. Terjemahan Kartini Kartono. Jakarta. RajaGrafindo.

Damrongpanit, Suntonrapot. (2019). From modern teaching to mathematics achievement: The mediating role of mathematics attitude, acchievement motivation, and selfefficacy. European Journal of Educatinal Researc Volume 8, Issue 3, 713-727 ISSN: 2165-8714 http://www.eu-jer.com/

Emmanuel Eric, Affum-Osei; Josephine, Eric Asante Adom Barnie; Solomon, Forkuoh Kwarteng. (2018). Reflection in Educational Sciences Vol. 2 No. 2, 2014 ISSN 2056- 5852.

Fauzia, Ellya. (2013). Pengaruh prestasi belajar dan motivasi berprestasi terhadap kesiapan berwirausaha pada siswa SMK Negeri 1 Cerme Gresik. Jurnal Ekonomi Pedidikan dan Kewirausahaan. Vol. 1, No. 1 Tahun 2013.

Hammerstein, Svenja., König, Christoph., Dreisörner, Thomas., \& Frey, Andreas. (2021) Effects of covid-19- related school closures on student achievementasSystematic Review. https://psyarxiv.com/mcnvk/

Hasbullah, Rahmat dan Moeins, Anoesyirwan. (2016). The infuence of profesionalism,Empirical study on High School Teachers in Karawang Regency. International Journal of Business and Commerce Vol. 5, No.06: [18- 36] 36).

Mahato, Aniruddha dan Barman, Pranab. (2019). Academic achievement motivation and academic performance of SC, ST Community Students in the District of Purulia. American Journal of $\quad$ Educational Research. 2019, 7(11), 872877. DOI: $\quad$ 10.12691/education-7-11-18

McClelland, D.C. (1987). Human Motivation. New York. Cambridge University Press.

Mozammel, Soleman., Ahmed, Umair., Shakar, Nawal. (2021). Covid-19 and online learning: critical insights for academic achievement. Ilkogretim Online Elementary Education Online, Year; Vol 20 (Issue 4): pp. 1452-1457 http://ilkogretim-online.org doi: 10.17051/ilkonline.2021.04.166

Mussen, Paul Henry, dkk. (1984). Child Development and Personality. Harper \& Row, Inc. Alih bahasa: FX. Budiyanto, dkk. Ctakan II tahun 1994. copyright dalam bahasa Indonesia. 1989. Jakarta: Penerbit Arcan.

Sarangi, C. (2015). Achievement motivation of the High School Students : a case study among different communities of Goalpara District of Assam. Journal of Education and Practice, 6(19), 140-145

Sugiyanto. (2009). Kontribusi Motivasi Berprestasi terhadap Prestasi Akademik Siswa Kelas XI SMA Negeri 10 Semarang. Paradigma, No. 08 Tahun IV, Juli 2009

Sardiman. (2014). Interaksi dan Motivasi Belajar Mengajar. Jakarta. Rajawal Pres.

Yuni., Astuti. (2019). Achievement motivation and the student's speaking performance. Journal of Education of English as Foreign Language. Vol.2, No. 2 (2019).

Yusuf, Syamsu dan Ahmad J. Nurihsan. (2011). Landasan Bimbingan dan Konseling. Bandung. PT Remaja Rosdakarya.

Wedhayanti1, Gitta Citra; Suarni, Ni Ketut; Dantes, Nyoman. (2020). Development of achievement motivation instruments in High School Students. Bisma The Journal of Counseling Volume 4 Number 2, 2020, pp 146- 153 ISSN: Print 25983199 - Online 2598-3210. 